\title{
A microanatomical and histological study of the postcranial dermal skeleton in the Devonian sarcopterygian Eusthenopteron foordi
}

Louise Zylberberg, François J. Meunier, and Michel Laurin

Acta Palaeontologica Polonica 55 (3), 2010: 459-470 doi: http://dx.doi.org/10.4202/app.2009.1109

The fin rays and two types of scales (enlarged and regular) of the Devonian sarcopterygian Eusthenopteron foordi are redescribed using light, scanning and transmission electron microscopy. The fin rays consist of lepidotrichia composed of ossified, jointed and branched segment pairs. The basal segments are cylindrical, but more distal elements are crescentic in section. The distribution of Sharpey's fibres varies along the lepidotrichia. In the proximal segments, lateral bundles form a belt connecting adjacent hemisegments. In the distal segments, thin bundles are restricted to the area facing the fin surface. Both enlarged and regular scales have a similar spatial organisation. They are composed of a superficial highly mineralised layer covering a thick basal plate where the fibrils are distributed in superimposed strata forming a plywood-like structure. Nevertheless, the enlarged and regular scales differ in their shape, in the mineralised tissues of the superficial layer, and in the organisation of the plywood-like structure. The superficial layer of the enlarged scales is composed of parallel-fibered bone covering a deeper layer of woven-fibered bone. The basal plate is made of an orthogonal plywood-like structure. The thin, lamellar, imbricated regular scales display the characteristics of elasmoid scales. The mineralised tissue forming the superficial layer resembles that of extant teleost scales. In the basal plate, the twisted plywood-like structure is composed of closely packed fibrils that are preserved down to the ultrastructural level owing to the persistence of bridges connecting the fibrils. The enlarged and the regular scales of Eusthenopteron foordi do not present superficial odontodes, in contrast to ancestral thick rhomboid scales. The disappearance of enamel/enameloid and dentine may be related to the evolutionary trend towards a lightening of the dermal skeleton that would improve the swimming abilities of the animal. The characteristics of the dermal skeleton of Eusthenopteron foordi support the hypothesis that this process began early in osteichthyans.

Key words: Sarcopterygii, Tetrapodomorpha, Tristichopteridae, Eusthenopteron, fin ray, elasmoid scales, paleohistology, transmission electron microscopy, Devonian. 
Louise Zylberberg [louise.zylberberg@upmc.fr], CNRS UMR 7193, Université Pierre et Marie Curie, ISTEP, Equipe Biominéralisations et Paléoenvironnements, 4 place Jussieu, BC19, 75252 Paris cedex 05, France; François J. Meunier [meunier@mnhn.fr ], CNRS UMR 7208, Biologie des organismes et écosytèmes aquatiques, Département des Milieux et Peuplements Aquatiques, Muséum National d'Histoire Naturelle, Case Postale 26, 43 rue Cuvier, 75231 Paris cedex 05, France; Michel Laurin [michel.laurin@upmc.fr], CNRS UMR 7207, "Centre de Recherches sur la Paléobiodiversité et les Paléoenvironnements”, Muséum National d'Histoire 3 Naturelle, Bâtiment de Géologie, Case Postale 48, 43 rue Buffon, F-75231 Paris Cedex 05 France.

This is an open-access article distributed under the terms of the Creative Commons Attribution License (for details please see creativecommons.org), which permits unrestricted use, distribution, and reproduction in any medium, provided the original author and source are credited. 